\title{
Modification of the Membrane Composition of Mycoplasma mycoides subsp. capri by the Growth Medium
}

\author{
By D. B. ARCHER \\ Sub-Department of Chemical Microbiology, Department of Biochemistry, \\ University of Cambridge, Cambridge CB2 I $Q W$
}

(Received 20 November 1974; revised 22 January 1975)

\begin{abstract}
SUMMARY
Mycoplasma mycoides subsp. capri was grown in different media. The amounts of the lipids in these media were varied, resulting in altered lipid compositions of the cells. Lowering the amounts of cholesterol in the media resulted in less cholesterol incorporation into the cell lipid, with a concomitant decrease in the amount of phospholipid. The changes in the phospholipid/cholesterol ratio in the mycoplasmas were very small compared with the large changes in the amount of cholesterol which occurred when the cholesterol content in the medium was altered. Changes in the amounts of glycolipid and glyceride in the cell lipid also resulted from alterations of the cholesterol concentration in the media. Under these conditions cells with reduced cholesterol contents were more sensitive to lysis by digitonin. No changes were observed in the polyacrylamide gel electrophoretic pattern of cellular or membrane proteins when the cholesterol was replaced by other sterols.
\end{abstract}

\section{INTRODUCTION}

The use of a defined growth medium is an essential requirement for any controlled modification of the chemical composition of a micro-organism. Mycoplasmas are only capable of limited metabolism of the lipid components of their cell membranes and are dependent on preformed lipid precursors such as fatty acids and sterols for good growth. By controlling the composition of a growth medium defined for fatty acids and sterol, the lipid composition of mycoplasmas grown in that medium may be modified.

No modification of cholesterol that was incorporated from the growth medium was observed in Mycoplasma strains v5 and Y (Rodwell, 1963) or in Mycoplasma PG3 among other species (Argaman \& Razin, I965). Fatty acids were not modified in Mycoplasma strain Y (Rodwell \& Peterson, I97I) but were in Acholeplasma laidlawii strain B (McElhaney \& Tourtellotte, 1970).

Rodwell (I969) described a partially defined medium, C2, containing an uncharacterized component, 'fraction C', a protein component derived from bovine serum, that acted as a sterol carrier. The fatty acids in the medium are bound to bovine serum albumin. The Edward medium (Razin, 1963) is another medium which, although it is much less well defined than the $\mathrm{C}_{2}$ medium, is often used for growth of mycoplasmas. This paper is concerned with the growth and chemical characterization of Mycoplasma mycoides subsp. capri (Mycoplasma $\mathrm{PG} 3$ ) under a variety of culture conditions in these and other media. 


\section{METHODS}

Organism. The organism used in this study was Mycoplasma mycoides subsp. capri (NCTTIOI37), obtained from the Mycoplasma Reference Laboratory, Central Public Health Laboratory, London, N.W. 9.

Maintenance and estimation of growth. Freeze-dried cultures were stored at $-20{ }^{\circ} \mathrm{C}$. All growth was at $37^{\circ} \mathrm{C}$, estimated by the $E_{420}$ using a Zeiss spectrophotometer model PMQII. Purity of cultures was examined by growth on Hayflick's agar (Chanock, Hayflick \& Barile, I962) in the presence of antiserum discs obtained from Dr R. H. Leach at the Mycoplasma Reference Laboratory, and by microscopic examination.

Growth media. Hayflick's medium was used as described by Chanock et al. (1962). Rodwell's (I969) C2 medium was used except for the following alterations to concentrations: adenine, guanine and uracil, $20 \mathrm{mg} / \mathrm{l}$; thymine, $10 \mathrm{mg} / 1$; charcoal-treated bovine serum albumin, $\mathrm{I} \cdot 0 \mathrm{~g} / \mathrm{l}$; pronase digest of fraction $\mathrm{C}, 0.2 \mathrm{~g} / \mathrm{l}$; sodium oleate and sodium palmitate, $0.025 \mathrm{~mm}$ each; cholesterol or other sterols, between $0.0 \mathrm{I}$ and $0.08 \mathrm{~mm}$ according to experimental requirements.

In a variation of the $\mathrm{C}_{2}$ medium, a crude mannan preparation (Thompson, Knights \& Parks, I973) at $\mathrm{I} g / 1$ replaced fraction $\mathrm{C}$. This medium has been designated $\mathrm{Cm}$. Modified Edward medium (Razin, 1963) was used, but with I mg fatty acid-free BSA (Sigma)/ml plus $0.025 \mathrm{~mm}$ sodium oleate, $0.025 \mathrm{~mm}$ sodium palmitate, and cholesterol between $0.0 \mathrm{I}$ and $0.08 \mathrm{~mm}$. Harvesting of cells at late exponential phase of growth was performed by centrifugation on an MSE I 8 high speed centrifuge for I 5 min at $15000 \mathrm{~g}$, and the organisms washed five times in $0.02 \mathrm{M}$-tris- $\mathrm{HCl} \mathrm{pH} 7 \cdot 0$, containing o. or $\mathrm{M}-\mathrm{MgCl}_{2} \cdot 6 \mathrm{H}_{2} \mathrm{O}$.

Assessment of osmotic fragility and sensitivity to digitonin. Osmotic fragility was determined by adding a washed suspension of mycoplasma to either distilled water or solutions of varying tonicity at the required temperature and recording the decrease with time in extinction at $420 \mathrm{~nm}$. Sensitivity to digitonin (up to $50 \mu \mathrm{g} / \mathrm{ml}$ ) was determined by suspending washed mycoplasma in a solution of digitonin containing $0.0 \mathrm{I} \mathbf{M}-\mathrm{MgCl}_{2}$ and proceeding as with the measurement of osmotic fragility.

Preparation of membranes. Membranes were prepared either by digitonin treatment in the presence of $0.01 \mathrm{M}-\mathrm{MgCl}_{2}$ (Rottem \& Razin, 1972) or by ultrasonic treatment. A Mullard sonicator operating at about $600 \mathrm{~W}$ for periods totalling $\mathrm{I} 5 \mathrm{~min}$ resulted in about $90 \%$ cell breakage. The membranes were separated from unbroken cells by centrifugation through sucrose density gradients.

Polyacrylamide gel electrophoresis of cell and membrane proteins. The protein-solubilization procedure was as described by Fairbanks, Steck \& Wallach (197I). Samples of $100 \mu \mathrm{g}$ protein were separated on 10 or $12.5 \%$ cross-linked gels containing $0 . \mathrm{I} \%(\mathrm{w} / \mathrm{v})$ SDS with tris-glycine buffer containing $0.1 \%(\mathrm{w} / \mathrm{v}) \mathrm{SDS}$ at $3 \mathrm{~mA} /$ tube. The Fairbanks staining procedure was used, destaining in $10 \%(\mathrm{v} / \mathrm{v})$ acetic acid at $37{ }^{\circ} \mathrm{C}$. The protein band patterns were recorded on a Joyce automatic recording microdensitometer model MKIIIC. Standard protein markers were also run as molecular weight indicators.

Extraction of lipids. Lipids were extracted from both intact cells and membrane preparations. The cell and membrane pellets formed after centrifugation were resuspended in a minimum volume of methanol before the addition of approximately twenty volumes of chloroform-methanol $(2: \mathrm{I}, \mathrm{v} / \mathrm{v})$. Two successive extractions were made with chloroformmethanol $(2: \mathrm{I}, \mathrm{v} / \mathrm{v})$, the first at room temperature for $6 \mathrm{~h}$ and the second at room temperature overnight. The extracts were pooled, washed twice with water and four times with 
chloroform-methanol-water ( $3: 48: 47$, by vol.) (Longley, Rose \& Knights, 1968). The solvent was removed by evaporation under $\mathrm{N}_{2}$.

Fractionation and qualitative analyses of neutral and polar lipids. The neutral and polar lipids were separated by silicic acid chromatography (Russell, 1974). Qualitative analysis of these lipids was performed by thin-layer chromatography. Microscope slides, coated with a $0.25 \mathrm{~mm}$ layer of Anasil $\mathrm{G}$, were activated just before use by heating at $\mathrm{I} 00{ }^{\circ} \mathrm{C}$ for $\mathrm{I} \mathrm{h}$. The neutral lipids were developed in petroleum ether (b.p. 40 to $60^{\circ} \mathrm{C}$ )-diethyl ether-acetic acid $(80: 20: 2$, by vol.) and the polar lipids with chloroform-methanol-acetic acid-water (25: I 5:4:2, by vol.) (Longley et al. 1968). The lipid components were visualized by iodine absorption or by charring, and characterized by group specific sprays (Waldi, 1965) and also by co-chromatography with authentic standards.

Quantitative analyses. Protein was estimated using Folin's reagent (Lowry et al. I95I). Hexose was estimated by the anthrone procedure using a glucose standard (Trevelyan \& Harrison, 1952). Glycolipid was estimated from the hexose analysis of the whole lipid extract, assuming a glycolipid structure such as that found in Acholeplasma laidlawii (Shaw, Smith \& Koostra, I968). RNA was estimated by the orcinol method (Herbert, Phipps \& Strange, 197I) and DNA by a modified Burton technique (Giles \& Myers, 1965). Total phosphorus was assayed by the method of Chen, Toribara \& Warner (I956). The phospholipid contents were calculated from the phosphate contents of lipid extracts by the method of Hunter \& Rose (1972). Glycerides were estimated according to the method described by Van Handel \& Zilversmit (I957) and free fatty acids by the method of Heinen \& De Vries (I966). Ergosterol was assayed according to Breivik \& Owades (I957). Cholesterol up to $50 \mu \mathrm{g}$ was estimated by the $\mathrm{FeCl}_{3}$ method (MacIntyre \& Ralston, I954), but for amounts of cholesterol between I and $5 \mu \mathrm{g}$ a modification of the method of Rudel \& Morris (I973) was used: the lipid sample was dissolved in chloroform and transferred to a small tube, after which the solvent was removed by evaporation under nitrogen. Then $0.03 \mathrm{ml} 33 \%(\mathrm{w} / \mathrm{v})$ $\mathrm{KOH}$ and $0.3 \mathrm{ml} 96 \%$ ethanol were added and mixed. This mixture was heated at $60{ }^{\circ} \mathrm{C}$ for I $5 \mathrm{~min}$, cooled, and $0.5 \mathrm{ml}$ water was added. Hexane $(0.5 \mathrm{ml})$ was added and, after mixing, the hexane layer was removed. This was repeated three times, the hexane layers were pooled and the hexane removed by evaporation under nitrogen. Then $0.5 \mathrm{ml}$ of the $O$-phthalaldehyde reagent (Zlatkis \& Zak, I969) was added and mixed. After Io min, the $E_{550}$ was measured using minicells in a Zeiss spectrophotometer. An $E_{550}$ of 0.26 corresponded to I $\mu \mathrm{g}$ cholesterol.

Gas-liquid chromatography. Fatty acids and sterols were analysed by g.l.c. using a Pye series 104 chromatograph equipped with dual-flame ionization detectors. Lipid samples were refluxed with methanolic $\mathrm{KOH}(3 \mathrm{M})$ for $2 \mathrm{~h}$ to saponify fatty acid esters. Free sterols were extracted into heptane and the mixture acidified with $\mathrm{HCl}$ for the extraction of fatty acids by heptane. Before analysis by g.l.c. the fatty acids were transmethylated (Nichols \& Moorhouse, 1969).

The fatty acid analyses were performed on a $5 \mathrm{ft}$ column of $10 \%(\mathrm{w} / \mathrm{w})$ polyethylene glycol adipate (PEGA) on 100 to 200 mesh celite. Argon flow was $40 \mathrm{ml} / \mathrm{min}$ and the column temperature was $190^{\circ} \mathrm{C}$.

The sterol analyses were performed on a $9 \mathrm{ft}$ column of $3.5 \%(\mathrm{w} / \mathrm{w})$ polydimethylsioloxane (JXR) on 100 to 200 mesh gas chrome Q. Argon flow was at $60 \mathrm{ml} / \mathrm{min}$ and the column temperature was $240^{\circ} \mathrm{C}$.

Peaks were identified by comparison of their retention times with those of authentic standards, and in the case of the fatty acids by comparing retention times on a James plot (James \& Martin, I952). 
Table I. The chemical compositions of cells and membranes grown in $\mathrm{C} 2$ medium

The medium contained $0.08 \mathrm{~mm}$-cholesterol, $0.025 \mathrm{~mm}$-sodium oleate and $0.025 \mathrm{~mm}$-sodium oleate as the only lipid components.

\begin{tabular}{lrc} 
& \multicolumn{2}{c}{ Dry wt (\%) } \\
Cells & $\begin{array}{c}\text { Digitonin } \\
\text { membranes }\end{array}$ \\
RNA & II.4 & 0 \\
RNA & $22 \cdot 8$ & $7 \cdot 3$ \\
Protein & $34 \cdot 4$ & $37 \cdot 9$ \\
Lipid & $24 \cdot 2$ & $47 \cdot 0$ \\
Hexose & $4 \cdot 7$ & II $\cdot 4$ \\
$\quad$ Total & $97 \cdot 5$ & 103.6
\end{tabular}

Materials. Organic solvents were redistilled once before use. Fatty acid standards were obtained from the Hormel Institute, Austin, Minnesota, U.S.A., and shown to be up to $99 \%$ pure by g.l.c. analysis. Cholesterol was obtained from Hopkin and Williams. All other sterols were obtained from Sigma chemicals and with the exception of $\beta$-sitosterol $(60 \%$ pure) were shown to be pure by g.l.c. analysis.

$O$-phthalaldehyde was obtained from BDH. All other chemicals were Analar grade whenever possible.

\section{RESULTS}

Hayflick's, C2 and Edward media all supported good growth of the organism with doubling times of about 4 to $5 \mathrm{~h}$ and a maximum yield of $0.5 \mathrm{mg}$ dry wt mycoplasma $/ \mathrm{ml}$ culture. No growth occurred in the absence of sterol or of palmitic or oleic acid. Mycoplasma PG3 can adapt to growth in very low concentrations of cholesterol (Rottem et al. 1973) but for our present work concentrations lower than 0.0 I $\mathrm{mm}$ were not used. The cholesterol could be replaced by $5 \alpha$-cholestan- $3 \beta$-ol, ergosterol or $\beta$-sitosterol but not by $5 \beta$-cholestan- $3 \alpha$-ol. This may reflect the requirement for a $3 \beta$ hydroxyl group for incorporation of a sterol into a membrane (De Kruyff et al. I973). Growth in $\mathrm{Cm}$ was not as good as in $\mathrm{C}_{2}$ although $\mathrm{Cm}$ may be used in preference to $\mathrm{C}_{2}$ because of the difficulty in preparing fraction C. A doubling time of $8 \mathrm{~h}$ with a maximum yield of $0.2 \mathrm{mg}$ dry $\mathrm{wt} / \mathrm{ml}$ was obtained when Mycoplasma $\mathrm{PG} 3$ was grown in $\mathrm{Cm}$.

\section{Chemical characterization}

The gross chemical compositions of cells and digitonin-prepared membranes are given in Table I. The apparent RNA contents may be high because the orcinol in the assay mixture may react with the galactan present in the perchloric acid extract. Indeed, Buttery \& Plackett (I960) claimed to have identified small amounts of ribose in the galactan of $M$. mycoides var. mycoides. The high hexose content of the membranes will reflect the presence of digitonin in the membrane.

In the $\mathrm{C} 2, \mathrm{Cm}$ and Edward media the only sterols present in the membranes were those which had been added to the media. The sterol and fatty acid contents of mycoplasma grown in Hayflick's medium were complex, reflecting the complexity of the medium (Table 2). Of the fatty acid contents of cells grown in the other media, more than $98 \%$ of the fatty acids were derived without modification from those added to $\mathrm{C} 2$ and $\mathrm{Cm}$, compared with more than $90 \%$ in the Edward medium. The fatty acid compositions of cells grown in the Edward medium containing different concentrations of cholesterol or ergosterol are shown in Tables 3 and 4 , 
Table 2. The fatty-acid composition of Mycoplasmà $\mathrm{PG} 3$ grown in Hayflick's medium

Fatty acid methyl esters were analysed by gas-liquid chromatography, the species recognized by constructing James' plots of the fatty acids before and after hydrogenation (James \& Martin, 1952) and by co-chromatography with authentic standards.

$\begin{array}{cccc}\text { Fatty acid } & \text { Composition }(\%) & \text { Fatty acid } & \text { Composition }(\%) \\ * & 4 \cdot \mathrm{I} 6 & \mathrm{I} 6: \mathrm{I} & 7 \cdot 54 \\ \mathrm{I} 2: 0 & 3 \cdot 05 & \mathrm{I} 7: 0 & 2 \cdot 20 \\ * & 4 \cdot 00 & 17: \mathrm{I} & 2 \cdot 70 \\ \text { I4:0 } & 3 \cdot 23 & \mathrm{I} 8: 0 & 9 \cdot 35 \\ * & 4 \cdot 40 & 18: \mathrm{I} & \mathrm{I} 2 \cdot 72 \\ \text { I5:0 } & 3 \cdot 9 \mathrm{I} & \mathrm{I} 9: 0 & 3 \cdot 69 \\ \text { I5:I } & 2 \cdot 75 & \mathrm{I} 9: 1 & \mathrm{I} \cdot \mathrm{IO} \\ \text { I6:0 } & 35 \cdot 50 & \end{array}$

Table 3. The fatty acid composition of Mycoplasma $\mathrm{PG} 3$ grown in different concentrations of cholesterol in Edward medium

\begin{tabular}{|c|c|c|c|}
\hline \multirow[b]{2}{*}{ Fatty acid } & \multicolumn{3}{|c|}{ Composition $(\%)$} \\
\hline & $08 \mathrm{C}^{*}$ & $04 C^{*}$ & or $C^{*}$ \\
\hline I $2: I$ & I. 15 & $1 \cdot 80$ & $1 \cdot 93$ \\
\hline $14: 0$ & $4 \cdot 82$ & $3 \cdot 12$ & $2 \cdot 36$ \\
\hline $16: 0$ & $56 \cdot 40$ & $58 \cdot 30$ & $62 \cdot 00$ \\
\hline I6: I & 3.53 & 3.44 & $2 \cdot 36$ \\
\hline $18: 0$ & $\mathrm{I} \cdot 44$ & $1 \cdot 35$ & $I \cdot 30$ \\
\hline I $8: 1$ & $32 \cdot 80$ & $31 \cdot 80$ & $30 \cdot 20$ \\
\hline $16: 0$ to $18: 1$ ratio & $I \cdot 72$ & $\mathrm{I} \cdot 84$ & $2 \cdot 05$ \\
\hline
\end{tabular}

* $08 \mathrm{C}, 04 \mathrm{C}$ and or $\mathrm{C}$ represent $0.08,0.04$ and $0.01 \mathrm{~mm}$-cholesterol in the medium, respectively.

Table 4. The fatty acid composition of Mycoplasma $\mathrm{PG} 3$ grown in different concentrations of ergosterol in Edward medium

\begin{tabular}{|c|c|c|c|}
\hline \multirow[b]{2}{*}{ Fatty acid } & \multicolumn{3}{|c|}{ Composition $(\%)$} \\
\hline & $08 \mathrm{E}^{*}$ & $04 E^{*}$ & or $E^{*}$ \\
\hline I $2:$ I & 0.89 & 0.93 & 0.23 \\
\hline $14: 0$ & I 99 & $2 \cdot 2 \mathrm{I}$ & $I \cdot I 5$ \\
\hline $16: 0$ & 54.40 & $57 \cdot 10$ & $62 \cdot 40$ \\
\hline I6:I & $3 \cdot 88$ & $3 \cdot 22$ & $2 \cdot 59$ \\
\hline $18: 0$ & $2 \cdot 00$ & $2 \cdot 24$ & $1 \cdot 96$ \\
\hline I 8: I & 34.00 & $31 \cdot 10$ & $28 \cdot 90$ \\
\hline 19:0 & $2 \cdot 88$ & $2 \cdot 42$ & $2 \cdot 82$ \\
\hline $16: 0$ to $18: 1$ ratio & $1 \cdot 60$ & $1 \cdot 84$ & $2 \cdot 16$ \\
\hline
\end{tabular}

* $08 \mathrm{E}, 04 \mathrm{E}$ and or E represent $0.08,0.04$ and 0.01 mm-ergosterol in the medium, respectively.

respectively. Unlike the values reported by Rottem et al. (I973) for cholesterol-grown cells, these values indicate that there is very little $C_{18: 0}$ fatty acid present when none is added to the medium and that the medium is virtually free from endogenous fatty acids.

The composition of lipid extracted from cells grown in $\mathrm{C}_{2}$ medium containing different cholesterol contents is given in Table 5. The only phospholipids were cardiolipin, phosphatidyl glycerol and phosphatidic acid. The amount of cholesterol in $\mathrm{C}_{2}, \mathrm{Cm}$ and the Edward medium was altered to study the regulation of the phospholipid:cholesterol ratio 
Table 5. Analyses of lipids entracted from Mycoplasma PG3 grown with different cholesterol concentrations in $C_{2}$ medium

\begin{tabular}{|c|c|c|c|}
\hline \multirow[b]{2}{*}{ Lipid component } & \multicolumn{3}{|c|}{ Total lipids $(\%, w / w)$} \\
\hline & $08 \mathrm{C}^{*}$ & $04 C^{*}$ & or $\mathrm{C}^{*}$ \\
\hline Cholesterol & I $8 \cdot I$ & $I 4 \cdot I$ & $5 \cdot 2$ \\
\hline Total phospholipid & $64 \cdot 0$ & $54 \cdot 0$ & $2 I \cdot I$ \\
\hline Glycolipid & IO & 12 & 18 \\
\hline Free fatty acid & 5 & 5 & 5 \\
\hline Triglyceride & $3 \cdot 0$ & $5 \cdot 0$ & $12 \cdot 1$ \\
\hline Mono- and di-glyceride & $8 \cdot 5$ & 12.5 & $26 \cdot 5$ \\
\hline Total & $107 \cdot 6$ & $103 \cdot 6$ & $97 \cdot 9$ \\
\hline
\end{tabular}

Table 6. The cholesterol and total phospholipid contents, as a percentage of total extracted lipid, of Mycoplasma $\mathrm{PG}_{3}$ grown in three different media, each with different concentrations of cholesterol

Cholesterol Phospholipid Molar ratio of phospholipid to cholesterol

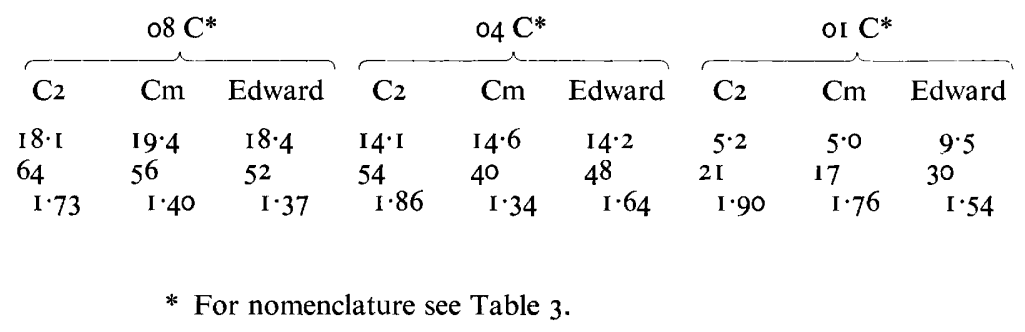

(Table 6). The range of phospholipid:cholesterol ratios, $I \cdot 34$ to $I \cdot 90$, is considered small in comparison with the three- to fourfold change in the cholesterol contents of the cell lipid.

\section{Osmotic and digitonin sensitivity}

Osmotic lysis of washed suspensions of Mycoplasma PG3 did not occur to any great extent no matter what growth conditions were used. Suspension in water at $37^{\circ} \mathrm{C}$ resulted in about $20 \%$ lysis of the cells after $30 \mathrm{~min}$, whereas at $0{ }^{\circ} \mathrm{C}$ no appreciable lysis occurred. The sensitivity to digitonin of $\mathrm{C} 2$-grown cells, grown in three different concentrations of cholesterol at $20^{\circ} \mathrm{C}$, is shown in Fig. I. The sensitivity at $37{ }^{\circ} \mathrm{C}$ was not significantly greater than at $20^{\circ} \mathrm{C}$, a result in agreement with those of Rottem \& Razin (1972). No lysis was observed at $0{ }^{\circ} \mathrm{C}$. For a given concentration of digitonin, cells with a lower amount of cholesterol in their membranes were lysed to a greater extent.

\section{Polyacrylamide gel electrophoresis}

Figure 2 shows the electrophoretic patterns of the proteins from whole-cell and membrane proteins run on $\mathrm{IO}$ and $\mathrm{I} 2 \frac{1}{2} \%$ cross-linked gels respectively. These patterns were all obtained when cholesterol was the only sterol present in the growth medium. When the cholesterol was replaced by ergosterol, $\beta$-sitosterol or $5 \alpha$-cholestan- $3 \beta$-ol, no differences in the protein band patterns were observed. 


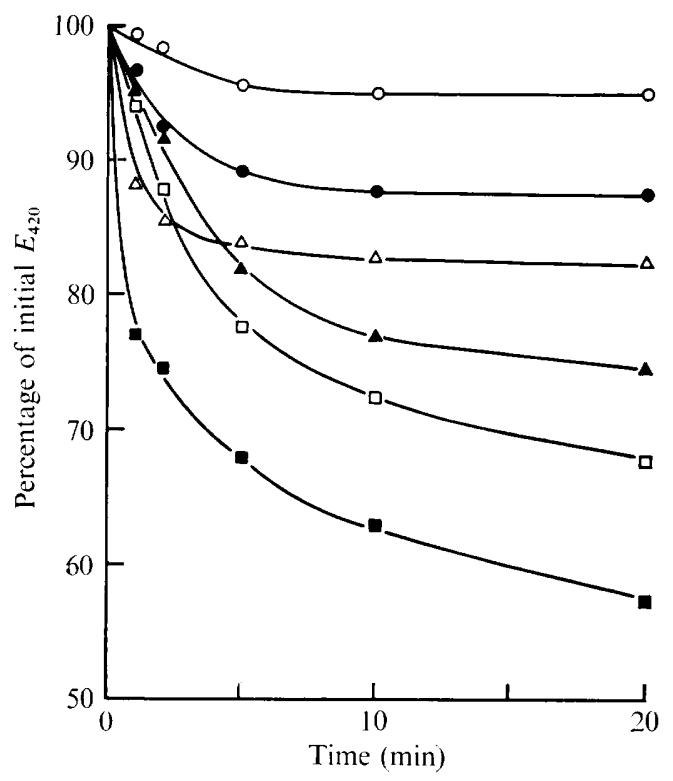

Fig. I. The sensitivity of Mycoplasma PG3 to digitonin. The cells were grown in $\mathrm{C} 2$ medium containing different concentrations of cholesterol and then washed and resuspended at $20{ }^{\circ} \mathrm{C}$ in buffer containing digitonin. Cells were either suspended in $25 \mu \mathrm{g}$ digitonin $/ \mathrm{ml}$ after growth in (O) $0.08 \mathrm{~mm},(\bullet) 0.04 \mathrm{~mm}$, or $(\Delta) 0.0 \mathrm{I} \mathrm{mM}$-cholesterol, or they were suspended in $50 \mu \mathrm{g}$ digitonin $/ \mathrm{ml}$ after growth in $(\Delta) 0.08 \mathrm{~mm},(\square) 0.04 \mathrm{~mm}$, or $(\boldsymbol{\square})$ 0.0 I mM-cholesterol.

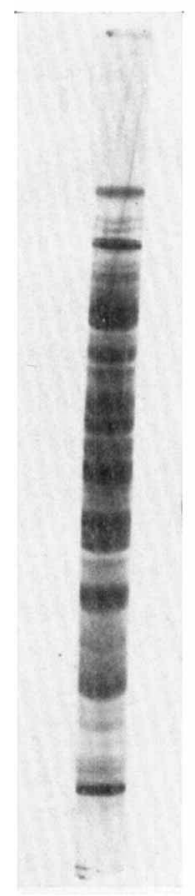

(a)

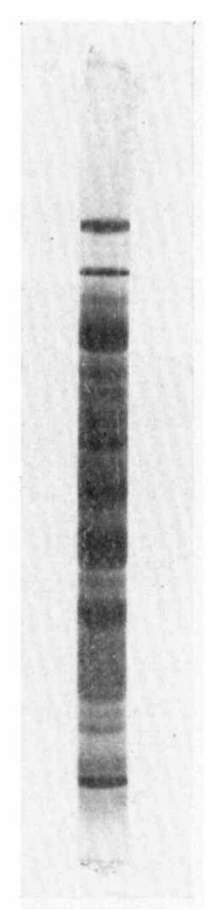

(b)

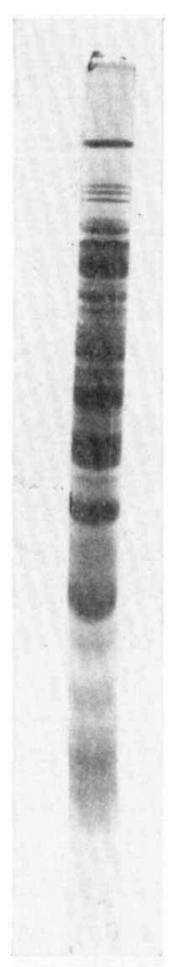

(c)

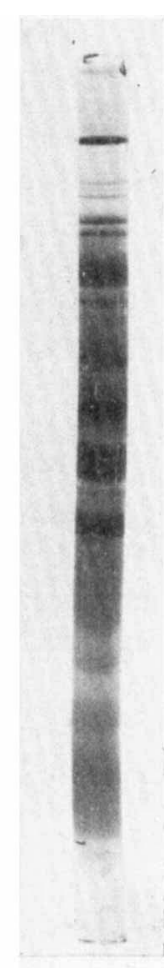

(d)

Fig. 2. Polyacrylamide gel electrophoretograms of whole cell and membrane proteins. (a) Whole cell protein, and $(b)$ membrane protein, on I0 \% cross-linked gel; $(c)$ whole cell protein, and $(d)$ membrane protein, on $12.5 \%$ cross-linked gel. 


\section{DISCUSSION}

When the cholesterol content of the cell membranes is varied by altering the concentration of cholesterol in the growth medium, it is apparent that both the cholesterol and phospholipid contents of the extracted lipids are controlled, since, in all experiments reported here, the phospholipid/cholesterol molar ratio was maintained between one and two. Healthy red blood cells which also have limited metabolic capabilities maintain such a ratio above unity although red blood cells from certain unhealthy subjects may show a much higher proportion of cholesterol (Vanderkooi et al. 1974). The metabolically-inactive myelin membrane has a phospholipid:cholesterol ratio of one (O'Brien \& Sampson, 1965). In artificial membranes, the sterol-phospholipid interaction has been extensively studied, a $3 \beta$ hydroxyl group being required on the sterol (De Kruyff et al. 1973) located next to phosphate in cholesterol-lecithin vesicles (Phillips \& Finer, 1974). The phospholipid: cholesterol ratio in artificial membranes influences the lipid fluidity (Ladbrooke, Williams \& Chapman, 1968) and controls many membrane properties such as ion permeability (De Gier, Mandersloot \& Van Deenen, 1968; Papahadjopoulos, 1970). The living cell can adapt to varying growth conditions by an alteration in the phospholipid and cholesterol content of its membrane, although other lipid components may well be important. The increase in the diglyceride content of cholesterol-depleted cells confirms the suggestion of Rottem et al. (1973) that this is so. The diglyceride and monoglyceride spots on the thinlayer chromatograms could not be separated sufficiently for independent quantitative analyses to be performed. In Acholeplasma laidlawii, glycolipids constitute about half of the total lipids, this proportion being unaffected by the concentration of cholesterol in the medium (Shaw et al. 1968). Acholeplasmas, unlike mycoplasmas, are not obligate sterol requirers, and so the increase in glycolipid content in Mycoplasma PG3 when the cholesterol content is reduced may not be contradictory to the result obtained with $A$. laidlawii. In these studies, the only fatty acids present in the medium were oleic and palmitic. When the cholesterol content of the cells was reduced, the ratio of the saturated to unsaturated fatty acids in the cells increased, contributing to the maintenance of lipid fluidity in the membrane, a result in agreement with that reported by Rottem et al. (1973). The precipitation of cholesterol by digitonin is well known (Moore \& Baumann, 1952) and digitonin has been used to differentiate between Mycoplasmas and Acholeplasmas (Freundt et al. 1973). Cholesterol confers digitonin sensitivity on bacterial L-phase variants (Razin \& Shafer, I969), and to lecithin liposomes (Hsu Chen \& Feingold, I973). That the mycoplasmas I used, grown under conditions such that their membrane cholesterol content was reduced, were repeatedly more sensitive to lysis by digitonin, must be attributed to the overall state of organization in the membrane rather than the cholesterol content alone.

The polyacrylamide gel electrophoretograms of cell and membrane proteins show that few differences exist. When densitometer traces of these gels are compared it can be seen that three proteins are missing from the membrane protein gel, in the high molecular weight region, and that four others are present in greatly reduced amounts compared with the whole-cell protein gel. No significant differences were apparent when the cholesterol was substituted by ergosterol, $\beta$-sitosterol or $5 \alpha$-cholestan- $3 \beta$-ol, although any differences may well be very limited particularly in view of the small differences between the whole-cell protein and membrane protein profiles. Pisetsky \& Terry (1972), looking at the effect of fatty acid composition on the membrane proteins of $A$. laidlawii, suggested that although the same proteins were always present quantitative differences did exist when the fatty acid composition was altered. 
I am grateful to Dr D. Kerridge for his interest and helpful suggestions and to Professor E. F. Gale and Dr P. Whittlestone for reading the manuscript. This work was performed during the tenure of a Medical Research Council Award.

\section{REFERENCES}

Argaman, M. \& RaZin, S. (I965). Cholesterol and cholesterol esters in mycoplasma. Journal of General Microbiology 38, I 53-I 68 .

BreiviK, O. N. \& OWADES, J. L. (I957). A semimicromethod for determining the percentages of ergosterol and 24,28 dehydroergosterol is described, from $5-100 \mathrm{mg}$ of yeast solids. Journal of Agricultural and Food Chemistry 5, 360-363.

Buttery, S. H. \& Plackett, P. (I960). A specific polysaccharide from Mycoplasma mycoides. Journal of General Microbiology 23, 357-368.

Chanock, R. M., Hayflick, L. \& Barile, M. F. (I962). Growth on artificial medium of an agent associated with atypical pneumonia and its identification as a PPLO. Proceedings of the National Academy of Sciences of the United States of America 48, 4I-49.

Chen, P. S., Toribara, T. Y. \& Warner, H. (1956). Microdetermination of phosphorus. Analytical Chemistry 28, 1756-1758.

De Gier, J., Mandersloot, J. G. \& Van Deenen, L. L. M. (1968). Lipid composition and permeability of liposomes. Biochimica et biophysica acta $\mathbf{1 5 0}, 666-675$.

De Kruyff, B., Demel, R. A., Slotboom, A. J., Van Deenen, L. L. M. \& Rosenthal, A. F. (I973). The effect of the polar headgroup on the lipid-cholesterol interaction: a monolayer and differential scanning calorimetry study. Biochimica et biophysica acta $307,1-19$.

Fairbanks, G., Steck, T. L. \& Wallach, D. F. H. (I97I). Electrophoretic analysis of the major polypeptides of the human erythrocyte membrane. Biochemistry ro, 2606-26I6.

Freundt, E. A., Andrews, B. E., Ernø, H., Kunze, M. \& Black, F. T. (I973). The sensitivity of mycoplasmatales to sodium-polyethanolsulfonate and digitonin. Zentralblatt für Bacteriologie, Parasitenkunde, Infektionskrankheiten und Hygiene (Abteilung I) 225, I04-I I 2.

Giles, K. W. \& Myers, A. (I965). An improved diphenylamine method for the estimation of deoxyribonucleic acid. Nature, London 206, 93.

HeINEN, W. \& DE VRIEs, H. (I966). A combined micro- and semi-micro-colorimetric determination of longchain fatty acids from plant cutin. Archiv für Mikrobiologie 54, 339-349.

Herbert, D., Phipps, P. J. \& Strange, R. E. (I97I). Determination of nucleic acids by sugar analysisdetermination of RNA by the Orcinol method. In Methods in Microbiology, vol. 5B, pp. 326-317. Edited by J. R. Norris and D. W. Robbins. New York and London: Academic Press.

Hsu Chen, C. C. \& Feingold, D. S. (I973). Polyene antibiotic action on lecithin liposomes: effect of cholesterol and fatty acyl chains. Biochemical and Biophysical Research Communications 51, 972-978.

HúNTER, K. \& Rose, A. H. (1972). Lipid composition of Saccharomyces cerevisiae as influenced by growth temperature. Biochimica et biophysica acta 260, 639-653.

JAMES, A. T. \& MARTIN, A. J. P. (I952). Gas-liquid partition chromatography: the separation and microestimation of volatile fatty acids from formic acid to dodecanoic acid. Biochemical Journal 50, 679-690.

Ladbrooke, B. D., Williams, R. M. \& Chapman, D. (I968). Studies on lecithin-cholesterol-water interactions by differential scanning calorimetry and X-ray diffraction. Biochimica et biophysica acta $\mathbf{5 0}$, 333-340.

Longley, R. P., Rose, A. H. \& KNights, B. A. (1968). Composition of the protoplast membrane from Saccharomyces cerevisiae. Biochemical Journal ro8, 40 I-4I 2.

Lowry, O. H., Rosebrough, N. I., Farr, A. L. \& Randall, R. J. (I95I). Protein measurement with the Folin phenol reagent. Journal of Biological Chemistry I93, 265-275.

Macintyre, I. \& Ralston, M. (I954). Direct determination of serum cholesterol. Biochemical Journal 56, Xliii $P$.

McElhaney, R. N. \& Tourtellotte, M. E. (1970). The relationship between fatty acid structure and the positional distribution of esterified fatty acids in phosphatidyl glycerol from Mycoplasma laidlawii B. Biochimica et biophysica acta 202, $120-\mathrm{I} 28$.

Moore, P. R. \& Baumann, C. A. (I952). Skin sterols. I. Colorimetric determination of cholesterol and other sterols in skin. Journal of Biological Chemistry 195, 61 5-621.

Nichols, B. W. \& Moorhouse, R. (I969). The separation, structure and metabolism of monogalactosyl diglyceride species in Chlorella vulgaris. Lipids 4, 3I I-3I 6. 
O'Brien, J. S. \& SAMpson, E. L. (I965). Lipid composition of the normal human brain: gray matter, white matter and myelin. Journal of Lipid Research 6, 537-544.

PapaHadjopoulos, D. (1970). Influence of cholesterol on the permeability of phospholipid membranes. In Circulation Supplements $11 \mathrm{I}-2 \mathrm{I}$, Abstract No. 77.

Phillips, M. C. \& Finer, E. G. (1974). The stoichiometry and dynamics of lecithin-cholesterol clusters in bilayer membranes. Biochimica et biophysica acta 356, 199-206.

Pisetsky, D. \& Terry, T. M. (I972). Are mycoplasma membrane proteins affected by variations in membrane fatty acid composition? Biochimica et biophysica acta 274, 95-IO4.

RAZIN, S. (1963). Osmotic lysis of mycoplasmas. Journal of General Microbiology 33, 47 I-475.

RAZIN, S. \& SHAFER, Z. (1969). Incorporation of cholesterol by membranes of bacterial L-phase variants. Journal of General Microbiology 58, 327-339.

Rodwell, A. W. (I963). The steroid growth requirement of Mycoplasma mycoides. Journal of General Microbiology 32, 9I-101.

Rodwell, A. W. (I969). The supply of cholesterol and fatty acids for the growth of mycoplasmas. Journal of General Microbiology 58, 29-37.

Rodwell, A. W. \& Peterson, J. E. (I97I ). The effect of straight-chain saturated, monoenoic and branchedchain fatty acids on growth and fatty acid composition of Mycoplasma strain Y. Journal of General Microbiology 68, I73-186.

RotTem, S. \& RAzIN, S. (1972). Isolation of mycoplasma membranes by digitonin. Journal of Bacteriology Iro, 699-705.

Rottem, S., Yashouv, J., Ne’eman, Z. \& Razin, S. (I973). Cholesterol in mycoplasma membranes. Composition, ultra-structure and biological properties of membranes from Mycoplasma mycoides var capri. Cells adapted to grow with low cholesterol concentration. Biochimica et biophysica acta 323, 495-508.

Rudel, L. L. \& Morris, M. D. (I973). Determination of cholesterol using $O$-phthalaldehyde. Journal of Lipid Research 14, 364-366.

Russell, N. J. (1974). The lipid composition of the psychrophilic bacterium Micrococcus cryophilus. Journal of General Microbiology 8o, 2 I 7-225.

Shaw, N., Sмith, P. F. \& Koostra, W. L. (1968). The lipid composition of Mycoplasma laidlawii strain B. Biochemical Journal 107, 329-333.

Thompson, E. D., Knights, B. A. \& PARks, L. W. (I973). Identification and properties of a sterol-binding polysaccharide isolated from Saccharomyces cerevisiae. Biochimica et biophysica acta 304, 132-141.

TreVelyan, W. E. \& Harrison, J. S. (I952). Studies on yeast metabolism. I. Fractionation and microdetermination of cell carbohydrates. Biochemical Journal 50, 298-303.

VANderkoor, J., Fischkoff, S., Chance, B. \& CoOper, R. A. (I974). Fluorescent probe analysis of the lipid architecture of natural and experimental cholesterol-rich membranes. Biochemistry 13, 1589-1595.

VAN HANDEl, E. \& Zilversmit, D. B. (I957). Micromethod for the direct determination of serum triglycerides. Journal of Laboratory and Clinical Medicine 50, 152-1 57.

WaLdI, D. (I965). In Thin Layer Chromatography, pp. 483-502. Edited by E. Stahl. New York: Academic Press.

ZlAtKis, A. \& ZAK, B. (I969). Study of a new cholesterol reagent. Analytical Biochemistry 29, I43-I 48. 